Proc. Indian Acad. Sci. (Chem. Sci.), Vol. 106, No. 3, June 1994, pp. 609-619.

(C) Printed in India.

\title{
Soft-chemical routes to synthesis of solid oxide materials ${ }^{\dagger}$
}

\author{
J GOPALAKRISHNAN*, S UMA, K KASTHURI RANGAN and \\ N S P BHUVANESH \\ Solid State and Structural Chemistry Unit, Indian Institute of Science, Bangalore 560012, \\ India
}

\begin{abstract}
We describe three different families of metal oxides, viz., (i) protonated layered perovskites, (ii) framework phosphates of NASICON and $\mathrm{KTiOPO}_{4}$ (KTP) structures and (iii) layered and three-dimensional oxides in the $\mathrm{H}-\mathrm{V}-\mathrm{W}-\mathrm{O}$ system, synthesized by 'softchemical' routes involving respectively ion-exchange, redox deintercalation and acid-leaching from appropriate parent oxides. Oxides of the first family, $\mathrm{H}_{y} \mathrm{~A}_{2} \mathrm{~B}_{3} \mathrm{O}_{10}(\mathrm{~A}=\mathrm{La} / \mathrm{Ca}$; $B=T i / N b$ ), exhibit variable Bronsted acidity and intercalation behaviour that depend on the interlayer structure. $\mathrm{V}_{2}\left(\mathrm{PO}_{4}\right)_{3}$ prepared by oxidative deintercalation from $\mathrm{Na}_{3} \mathrm{~V}_{2}\left(\mathrm{PO}_{4}\right)_{3}$ is a new host material exhibiting reductive insertion of lithium/hydrogen, while $\mathrm{K}_{0.5} \mathrm{Nb}_{0.5}$ $\mathrm{M}_{0.5} \mathrm{OPO}_{4}(\mathrm{M}=\mathrm{Ti}, \mathrm{V})$ are novel KTP-like materials exhibiting second harmonic generation of $1064 \mathrm{~nm}$ radiation. $\mathrm{H}_{x} \mathrm{~V}_{x} \mathrm{~W}_{1-x} \mathrm{O}_{3}$ for $x=0.125$ and 0.33 possessing $\alpha-\mathrm{MoO}_{3}$ and hexagonal $\mathrm{WO}_{3}$ structures, prepared by acid-leaching of $\mathrm{LiVWO}_{6}$, represent functionalized oxide materials exhibiting redox and acid-base intercalation reactivity.
\end{abstract}

Keywords. Synthesis of oxide materials; ion-exchange; intercalation/deintercalation; acid-leaching.

\section{Introduction}

Synthesizing inorganic solids, especially to specification, is a challenging task because, unlike organic/molecular compounds, the factors that determine the formation, stability, structure and properties of inorganic solids are poorly understood at present (DiSalvo 1990). Accordingly, there is a tremendous current interest towards developing novel routes to solid synthesis, based on chemical principles (Gopalakrishnan 1984; Rao 1993). Such chemical methods which enable syntheses of solids at low temperatures have an added advantage in that the stringent requirement of thermodynamic phase stability can be avoided, enabling stabilization of metastable phases under ambient conditions (Stein et al 1993). We have been pursuing soft-chemical/low-temperature synthesis of metastable phases of perovskite, $\mathrm{ReO}_{3}$, rocksalt and rutile-related structures for sometime (Rao and Gopalakrishnan 1987; Gopalakrishnan 1993). In this paper, we describe three different families of metal oxides synthesized by us in recent times using soft-chemical routes. They are (i) protonated layered perovskites, (ii) framework phosphates belonging to NASICON and $\mathrm{KTiOPO}_{4}$ (KTP) structures and (iii) layered and three-dimensional oxides in the $\mathrm{H}-\mathrm{V}-\mathrm{W}-\mathrm{O}$ system synthesized respectively by ion-exchange, redox deintercalation and acid-leaching of appropriate

\footnotetext{
* For correspondence

${ }^{+}$Contribution No. 936 from the Solid State and Structural Chemistry Unit.
} 
parent oxides. The new oxides, which could not have been synthesized by conventional high-temperature routes, exhibit interesting structure-property relationships of relevance to the design of solid materials for special applications.

\section{Experimental}

Protonated layered perovskites, $\mathrm{H}_{y} \mathrm{~A}_{2} \mathrm{~B}_{3} \mathrm{O}_{10}(\mathrm{~A}=\mathrm{La} / \mathrm{Ca} ; \mathrm{B}=\mathrm{Ti} / \mathrm{Nb})$, were prepared from the parent alkali metal analogues, $(\mathrm{K} / \mathrm{Rb})_{y} \mathrm{~A}_{2} \mathrm{~B}_{3} \mathrm{O}_{10}$, by ion-exchange in aqueous $\mathrm{HNO}_{3}$. Intercalation of organic bases was investigated by refluxing the host materials with a $10 \%$ solution of the base in $n$-heptane around $90^{\circ} \mathrm{C}$ for several days. Deintercalation of alkali metal from $\mathrm{Na}_{3} \mathrm{~V}_{2}\left(\mathrm{PO}_{4}\right)_{3}, \mathrm{~A}_{x}^{\prime} \mathrm{TiV}\left(\mathrm{PO}_{4}\right)_{3}\left(\mathrm{~A}^{\prime}=\mathrm{Na}, \mathrm{K}\right)$ and $\mathrm{KM}_{0.5} \mathrm{M}_{0.5}^{\prime} \mathrm{OPO}_{4}\left(\mathrm{M}=\mathrm{Nb}, \mathrm{Ta} ; \mathrm{M}^{\prime}=\mathrm{Ti}, \mathrm{V}\right)$ was investigated by passing chlorine through a suspension of the solid phosphate in $\mathrm{CHCl}_{3}$. Acid-leaching of $\mathrm{LiVWO}_{6}$ was carried out by treating the solid with varying concentrations of $\mathrm{HNO}_{3} / \mathrm{HCl}$ both over a water bath and under reflux. Oxidation state of the transition metal, where essential, was determined by potentiometric titration using $\mathrm{Ce}$ (IV) as an oxidizing agent. Solid products were characterized by EDX, X-ray powder diffraction and thermogravimetry. Second harmonic generation (SHG) intensities of KTP-related powder materials were measured using a pulsed $Q$-switched Nd:YAG laser.

\section{Results and discussion}

We employed three different soft-chemical routes, viz., ion-exchange in aqueous acids, oxidative deintercalation of alkali metal using chlorine in nonaqueous solvents and acid-leaching in aqueous acids to prepare the following series of layered and threedimensional oxide materials.

\subsection{Protonated layered perovskites}

There are two series of layered perovskites, one is the Ruddlesden-Popper series (Ruddlesden and Popper 1957, 1958) of the general formula, $\mathrm{A}_{2}^{\prime}\left[\mathrm{A}_{n-1} \mathrm{~B}_{n} \mathrm{O}_{3 n+1}\right]$, of which $\mathrm{Sr}_{4} \mathrm{Ti}_{3} \mathrm{O}_{10}$ is a typical $n=3$ member and the other is the Dion-Jacobson series (Dion et al 1981; Jacobson et al 1985) of the general formula, $\mathrm{A}^{\prime}\left[\mathrm{A}_{n-1} \mathrm{~B}_{n} \mathrm{O}_{3 n+1}\right]$, of which $\mathrm{CsCa}_{2} \mathrm{Nb}_{3} \mathrm{O}_{10}$ (Dion et al 1984) and $\mathrm{KLaNb}_{2} \mathrm{O}_{7}$ (Gopalakrishnan et al 1987) are typical $n=3$ and $n=2$ members. A few years back, we prepared a new series of titanates, $A_{2}^{\prime}\left[\mathrm{Ln}_{2} \mathrm{Ti}_{3} \mathrm{O}_{10}\right]$ where $A=K, \mathrm{Rb}$ and $\mathrm{Ln}=\mathrm{La}$ or rare earth (Gopalakrishnan and Bhat 1987), which are isostructural with $\mathrm{Sr}_{4} \mathrm{Ti}_{3} \mathrm{O}_{10}$. Members of both the series of oxides undergo facile ion-exchange in aqueous acids to yield protonated derivatives such as $\mathrm{H}_{2} \mathrm{La}_{2} \mathrm{Ti}_{3} \mathrm{O}_{10}$ and $\mathrm{HCa}_{2} \mathrm{Nb}_{3} \mathrm{O}_{10}$ retaining the parent layered perovskite structure. Of these, protonated oxides of the latter type are strong Bronsted acids intercalating a wide variety of organic bases (Jacobson et al 1987) including pyridine $\left(p K_{a}=5.3\right)$ and aniline $\left(p K_{a}=4 \cdot 6\right)$, while members of the former series do not show such an obvious acidic property.

In an attempt to understand the relation between acidic property and structure of the layered perovskite oxides, we prepared protonated oxides of the general formula $\mathrm{H}_{y} \mathrm{~A}_{2} \mathrm{~B}_{3} \mathrm{O}_{10}-\mathrm{H}_{1-x} \mathrm{La}_{x} \mathrm{Ca}_{2-x} \mathrm{Nb}_{3} \mathrm{O}_{10}(0<x<1), \mathrm{HCa}_{2-x} \mathrm{La}_{x} \mathrm{Nb}_{3-x} \mathrm{Ti}_{x} \mathrm{O}_{10}(0<x<2)$ 
Table 1. Composition and lattice parameters of representative protonated layered perovskites, $\mathrm{H}_{y} \mathrm{~A}_{2} \mathrm{~B}_{3} \mathrm{O}_{10}$.

\begin{tabular}{|c|c|c|c|}
\hline \multirow[b]{2}{*}{ Composition } & \multicolumn{2}{|c|}{ Lattice parameters $(\AA)$} & \multirow{2}{*}{$\begin{array}{c}\text { Structure } \\
\text { type }\end{array}$} \\
\hline & $a$ & $c$ & \\
\hline $\mathrm{HCa}_{2} \mathrm{Nb}_{3} \mathrm{O}_{10}$ & $3 \cdot 850(6)$ & $14 \cdot 379(3)$ & $\mathrm{CsCa}_{2} \mathrm{Nb}_{3} \mathrm{O}_{10}$ \\
\hline $\mathrm{H}_{0.5} \mathrm{La}_{0.5} \mathrm{Ca}_{1.5} \mathrm{Nb}_{3} \mathrm{O}_{10}$ & $3 \cdot 881(5)$ & $14 \cdot 39(1)$ & $\mathrm{CsCa}_{2} \mathrm{Nb}_{3} \mathrm{O}_{10}$ \\
\hline $\mathrm{HCaLaNb}_{2} \mathrm{TiO}_{10}$ & $3 \cdot 855(6)$ & $14 \cdot 41(6)$ & $\mathrm{CsCa}_{2} \mathrm{Nb}_{3} \mathrm{O}_{10}$ \\
\hline $\mathrm{HCa}_{0.5} \mathrm{La}_{1.5} \mathrm{Nb}_{1.5} \mathrm{Ti}_{1.5} \mathrm{O}_{10}$ & $3 \cdot 835(4)$ & $14 \cdot 39(6)$ & $\mathrm{CsCa}_{2} \mathrm{Nb}_{3} \mathrm{O}_{10}$ \\
\hline $\mathrm{HLa}_{2} \mathrm{Ti}_{2} \mathrm{NbO}_{10}{ }^{*}$ & $3 \cdot 832(5)$ & $14 \cdot 52(5)$ & $\mathrm{CsCa}_{2} \mathrm{Nb}_{3} \mathrm{O}_{10}$ \\
\hline $\mathrm{H}_{1.5} \mathrm{La}_{2} \mathrm{Ti}_{2.5} \mathrm{Nb}_{0.5} \mathrm{O}_{10}$ & $3 \cdot 832(6)$ & $27 \cdot 51(6)$ & $\mathrm{Sr}_{4} \mathrm{Ti}_{3} \mathrm{O}_{10}$ \\
\hline $\mathrm{H}_{2} \mathrm{La}_{2} \mathrm{Ti}_{3} \mathrm{O}_{10}$ & $3 \cdot 824(5)$ & $27 \cdot 40(6)$ & $\mathrm{Sr}_{4} \mathrm{Ti}_{3} \mathrm{O}_{10}$ \\
\hline $\mathrm{H}_{2} \mathrm{Ca}_{2} \mathrm{Nb}_{2} \mathrm{TiO}_{10}$ & $3 \cdot 844(6)$ & $28 \cdot 67(7)$ & $\mathrm{Sr}_{4} \mathrm{Ti}_{3} \mathrm{O}_{10}$ \\
\hline
\end{tabular}

*Anhydrous phase is unstable

and $\mathrm{H}_{2-x} \mathrm{La}_{2} \mathrm{Ti}_{3-x} \mathrm{Nb}_{x} \mathrm{O}_{10}(0 \leqslant x \leqslant 1)$, starting from the corresponding potassium or rubidium compounds by ion-exchange in aqueous $\mathrm{HNO}_{3}$. In table 1 we list the compositions and lattice parameters and, in figure 1 , the $\mathrm{X}$-ray powder diffraction (XRD) patterns of a few representative members. These show that $\mathrm{H}_{y} \mathrm{~A}_{2} \mathrm{~B}_{3} \mathrm{O}_{10}$ oxides adopt two different structures: for $y \leqslant 1$ in $\mathrm{H}_{y} \mathrm{~A}_{2} \mathrm{~B}_{3} \mathrm{O}_{10}\left(\mathrm{H}_{1-x} \mathrm{La}_{x} \mathrm{Ca}_{2-x} \mathrm{Nb}_{3} \mathrm{O}_{10}\right.$ and $\mathrm{HCa}_{2-x} \mathrm{La}_{x} \mathrm{Nb}_{3-x} \mathrm{Ti}_{x} \mathrm{O}_{10}$, the structure is primitive tetragonal, similar to $\mathrm{CsCa}_{2} \mathrm{Nb}_{3} \mathrm{O}_{10}$ and $\mathrm{HCa}_{2} \mathrm{Nb}_{3} \mathrm{O}_{10}$ (Jacobson et al 1986), and for $1<y \leqslant 2\left(\mathrm{H}_{2-x} \mathrm{La}_{2}\right.$ $\mathrm{Ti}_{3-x} \mathrm{Nb}_{x} \mathrm{O}_{10}$ ), on the other hand, the structure is body-centred tetragonal ( $14 / \mathrm{mmm}$ ) similar to the structures of $\mathrm{Sr}_{4} \mathrm{Ti}_{3} \mathrm{O}_{10}$ and $\mathrm{K}_{2} \mathrm{La}_{2} \mathrm{Ti}_{3} \mathrm{O}_{10}$. The difference between the two structures arises essentially from the stacking of the triple-perovskite $\left[\mathrm{A}_{2} \mathrm{~B}_{3} \mathrm{O}_{10}\right]$ layers in the $c$-direction. While the adjacent perovskite slabs are displaced by $(a+b / 2)$ translation giving a body-centred tetragonal cell for $\mathrm{Sr}_{4} \mathrm{Ti}_{3} \mathrm{O}_{10}$, there is no such displacement in the $\mathrm{CsCa}_{2} \mathrm{Nb}_{3} \mathrm{O}_{10}$ structure (figure 2).

The difference in the structure of $\mathrm{H}_{y} \mathrm{~A}_{2} \mathrm{~B}_{3} \mathrm{O}_{1}$, oxides appears to have a profound influence on the Bronsted acidity, as revealed by intercalation of $n$-alkylamines and other bases. While the members of $\mathrm{H}_{1-x} \mathrm{La}_{x} \mathrm{Ca}_{2-x} \mathrm{Nb}_{3} \mathrm{O}_{10}$ exhibit Bronsted acidity just as the parent $\mathrm{HCa}_{2} \mathrm{Nb}_{3} \mathrm{O}_{10}$ (Jacobson et al 1987), intercalating several organic bases including pyridine (table 2), $\mathrm{H}_{2} \mathrm{La}_{2} \mathrm{Ti}_{3} \mathrm{O}_{10}$ and $\mathrm{H}_{2-x} \mathrm{La}_{2} \mathrm{Ti}_{3-x} \mathrm{Nb}_{x} \mathrm{O}_{10}$ for $0<x \leqslant 0.75$ do not intercalate even strong bases such as piperidine $\left(p K_{a}=11.2\right)$ and guanidine $\left(p K_{a}=12 \cdot 5\right)$ (Uma et al 1993). The lack of Bronsted acidity for the protons of $\mathrm{H}_{2-x} \mathrm{La}_{2} \mathrm{Ti}_{3-x} \mathrm{Nb}_{x} \mathrm{O}_{10}(0 \leqslant x \leqslant 0 \cdot 75)$ seems to be due to the special interlayer structure arising from the displacement of perovskite slabs in the [1 110$]$ direction (figure 2). It is significant that even the isostructural $\mathrm{H}_{2} \mathrm{Ca}_{2} \mathrm{Nb}_{2} \mathrm{TiO}_{10}$ (table 1 ) is exactly similar to $\mathrm{H}_{2} \mathrm{La}_{2} \mathrm{Ti}_{3} \mathrm{O}_{10}$ in its acidic behaviour, revealing that the lack of Bronsted acidity of these solids is structural in origin rather than due to the intrinsic acidity of the protons attached to $\mathrm{TiO}_{6} / \mathrm{NbO}_{6}$ octahedra.

Recently, we prepared anion-deficient layered perovskites of the formula, $\mathrm{HCa}_{2}$ $\mathrm{Nb}_{3-x} \mathrm{M}_{x} \mathrm{O}_{10-x}(\mathrm{M}=\mathrm{Fe}, \mathrm{Al})$ for $0<x \leqslant 1 \cdot 0$, possessing structure and properties similar to the parent $\mathrm{HCa}_{2} \mathrm{Nb}_{3} \mathrm{O}_{10}$. Intercalation experiments suggest that while the oxygen vacancies in the perovskite slabs of the as-prepared materials are not ordered, the vacancies do seem to order in $\mathrm{ACa}_{2} \mathrm{Nb}_{2} \mathrm{AlO}_{9}(\mathrm{~A}=\mathrm{Cs}, \mathrm{H})$ on long annealing of 


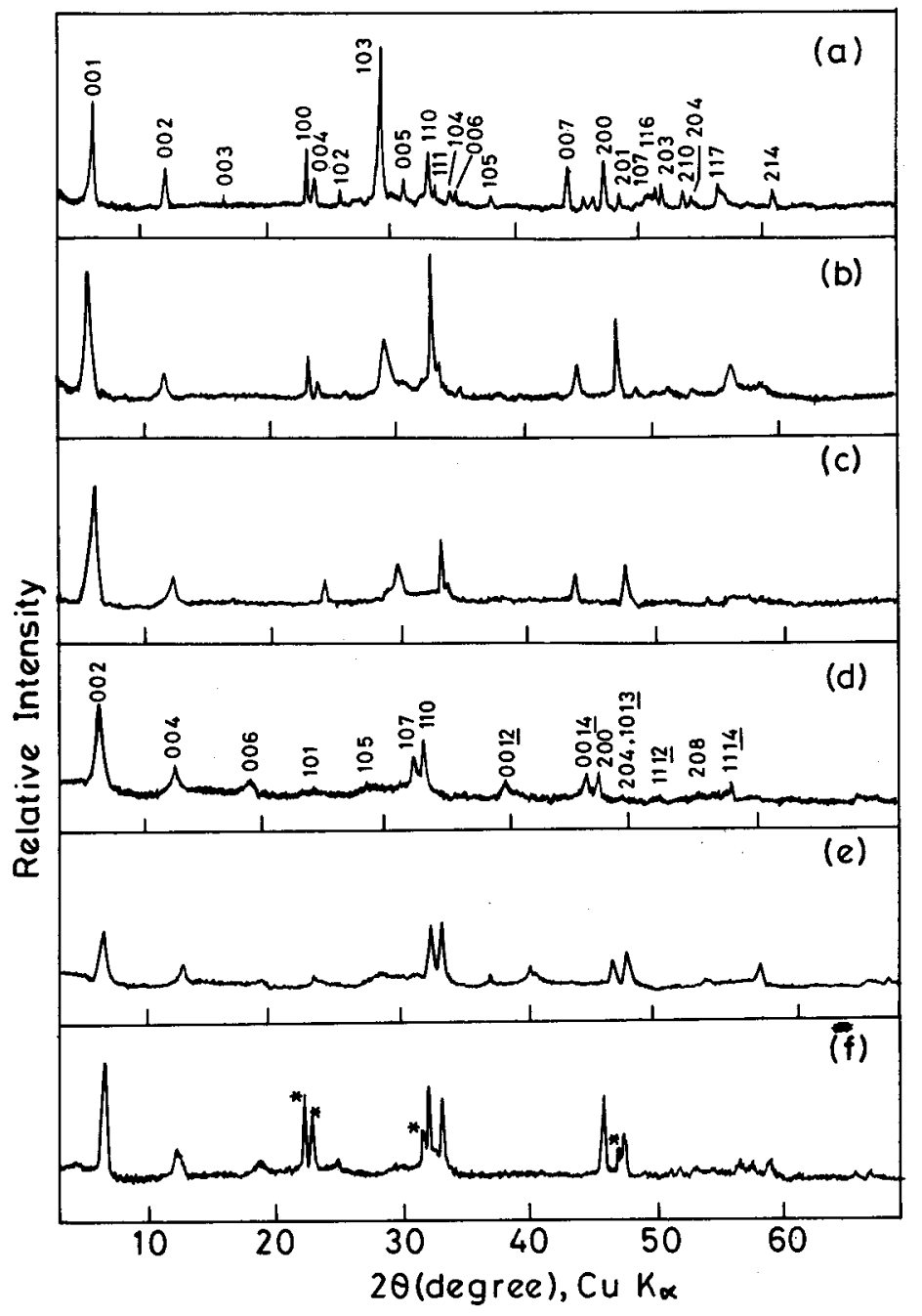

Figure 1. X-ray powder diffraction patterns of (a) $\mathrm{H}_{0.5} \mathrm{La}_{0.5} \mathrm{Ca}_{1.5} \mathrm{Nb}_{3} \mathrm{O}_{10}$, (b) $\mathrm{HCaLaNb}$ $\mathrm{TiO}_{10}$, (c) $\mathrm{HLa}_{2} \mathrm{NbTi}_{2} \mathrm{O}_{10}$, (d) $\mathrm{H}_{1 \cdot 5} \mathrm{La}_{2} \mathrm{Ti}_{2 \cdot 5} \mathrm{Nb}_{0.5} \mathrm{O}_{10}$, (e) $\mathrm{H}_{2} \mathrm{La}_{2} \mathrm{Ti}_{3} \mathrm{O}_{10}$ and (f) $\mathrm{H}_{2} \mathrm{Ca}_{2}$ $\mathrm{Nb}_{2} \mathrm{TiO}_{10}$. In (f), asterisks denote impurity phase.

the parent at $1000^{\circ} \mathrm{C}$, giving rise to octahedral $\left(\mathrm{NbO}_{6}\right)$-tetrahedral $\left(\mathrm{AlO}_{4}\right)$-octahedral $\left(\mathrm{NbO}_{6}\right)$ layer sequence in the triple perovskite slabs. This layer sequence is reminiscent of the brownmillerite structure (Colville and Geller 1971). Accordingly, $\mathrm{ACa}_{2} \mathrm{Nb}_{2} \mathrm{AlO}_{9}$ could be regarded the first examples of layered brownmillerites.

\subsection{Framework phosphates}

Phosphates of the formula, $\mathrm{A}_{x} \mathrm{M}_{2}\left(\mathrm{PO}_{4}\right)_{3}$, consisting of $\mathrm{M}_{2}\left(\mathrm{PO}_{4}\right)_{3}$ framework formed by corner-sharing of $\mathrm{MO}_{6}$ octahedra and $\mathrm{PO}_{4}$ tetrahedra crystallize mainly in the NASICON $\left[\mathrm{Na}_{3} \mathrm{Zr}_{2} \mathrm{PSi}_{2} \mathrm{O}_{12}\right]$ (Hong 1976) and the langbeinite $\left[\mathrm{K}_{2} \mathrm{Mg}_{2}\left(\mathrm{SO}_{4}\right)_{3}\right]$ (Zemann and Zemann 1957) (figure 3) structures. The structure adopted by a given 


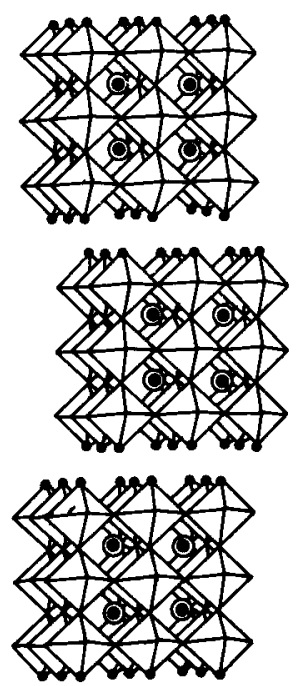

(a)

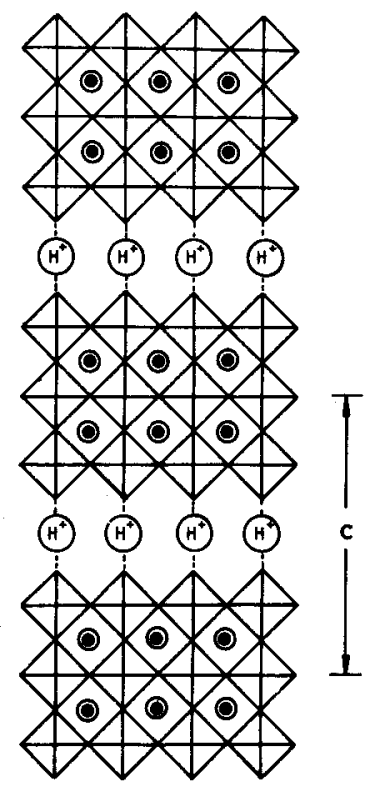

(b)

- H OLa/Ca

Figure 2. Idealized structures of (a) $\mathrm{H}_{2} \mathrm{La}_{2} \mathrm{Ti}_{3} \mathrm{O}_{10}$ and (b) $\mathrm{HCa}_{2} \mathrm{Nb}_{3} \mathrm{O}_{10}$.

Table 2. Composition and lattice parameters of representative intercalation compounds of $\mathrm{H}_{y} \mathrm{~A}_{2} \mathrm{~B}_{3} \mathrm{O}_{10}$.

\begin{tabular}{|c|c|c|c|c|}
\hline \multirow[b]{2}{*}{ Host } & \multirow[b]{2}{*}{ Guest amine } & \multirow{2}{*}{$\begin{array}{l}\text { Amine } \\
\text { content }\end{array}$} & \multicolumn{2}{|c|}{ Lattice parameters $(\AA)$} \\
\hline & & & $a$ & $c$ \\
\hline $\mathrm{H}_{050} \mathrm{La}_{0.50} \mathrm{Ca}_{1.50} \mathrm{Nb}_{3} \mathrm{O}_{10}$ & $n$-Decylamine & 0.50 & $3-885(5)$ & $34.00(1)$ \\
\hline $\mathrm{H}_{0.75} \mathrm{La}_{0.25} \mathrm{Ca}_{1.75} \mathrm{Nb}_{3} \mathrm{O}_{10}$ & n-Decylamine & 0.75 & $3 \cdot 880(5)$ & $34 \cdot 28(1)$ \\
\hline $\mathrm{HCa}_{2} \mathrm{Nb}_{3} \mathrm{O}_{10}$ & n-Decylamine & 0.95 & $3 \cdot 852(4)$ & $34 \cdot 57(7)$ \\
\hline $\mathrm{HCa}_{2} \mathrm{Nb}_{3} \mathrm{O}_{10}$ & Aniline & 0.90 & $3 \cdot 871(5)$ & $25 \cdot 39(6)$ \\
\hline $\mathrm{HCaLaNb}_{2} \mathrm{TiO}_{10}$ & n-Decylamine & 0.99 & $3 \cdot 854(5)$ & $34 \cdot 73(6)$ \\
\hline $\mathrm{HCaLaNb}_{2} \mathrm{TiO}_{10}{ }^{*}$ & Piperidine & 0.60 & $3 \cdot 868(5)$ & $23 \cdot 69(5)$ \\
\hline $\mathrm{HCaLaNb}_{2} \mathrm{TiO}_{10}$ & Pyridine & 0.60 & $3.858(4)$ & $18.93(2)$ \\
\hline $\mathrm{HCa}_{0.50} \mathrm{La}_{1 \cdot 50} \mathrm{Nb}_{1 \cdot 50} \mathrm{Ti}_{1 \cdot 50} \mathrm{O}_{10}$ & n-Decvlamine & $0-48$ & $3.848(7)$ & $35 \cdot 36(6)$ \\
\hline $\mathrm{HLa}_{2} \mathrm{Ti}_{2} \mathrm{NbO}_{10}{ }^{*}$ & Piperidine & 0.60 & $3.845(7)$ & $23.86(5)$ \\
\hline $\mathrm{HLa}_{2} \mathrm{Ti}_{2} \mathrm{NbO}_{10} *$ & Guanidine & 0.50 & $3.850(2)$ & $15 \cdot 71(2)$ \\
\hline
\end{tabular}

*Amine compounds are hydrated

$A_{x} M_{2}\left(P_{4}\right)_{3}$ depends on, among others, the size of the $A$ cation and the value of $x$. Interestingly, the NASICON framework is stable even without the A cation, e.g. $\mathrm{Nb}_{2}\left(\mathrm{PO}_{4}\right)_{3}$ (Leclaire et al 1989).

We prepared several transition metal phosphates of the formula, $A_{x} \mathbf{M}_{2}\left(\mathrm{PO}_{4}\right)_{3}$ for $\mathrm{A}=\mathrm{Na}$ or $\mathrm{K}$ and $\mathrm{M}=\mathrm{Ti}$ and/or $\mathrm{V}$, by a novel method involving hydrogen reduction 


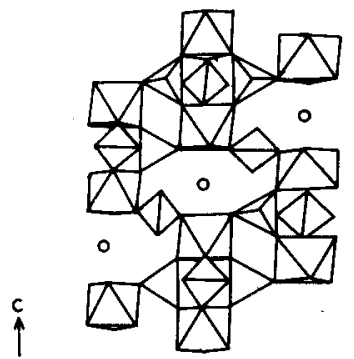

(a)

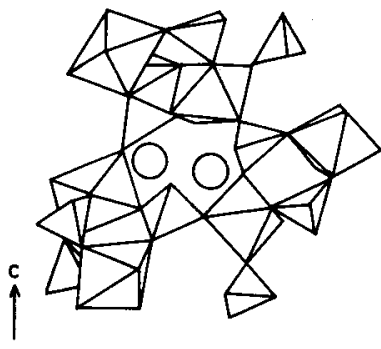

(b)

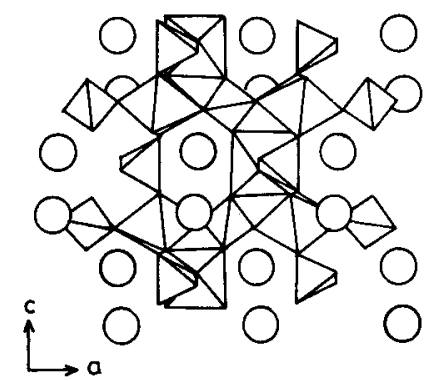

(c)

Figure 3. Framework structures of (a) NASICON, (b) langbeinite and (c) $\mathrm{KTiOPO}_{4}$.

Table 3. Composition, colour and lattice parameters of $A_{x} M_{2}\left(P_{4}\right)_{3}$.

\begin{tabular}{|c|c|c|c|c|c|c|}
\hline \multirow[b]{2}{*}{ Composition } & \multirow[b]{2}{*}{ Colour } & \multicolumn{2}{|c|}{$\begin{array}{l}\text { Reducing power } \\
\text { of the sample }\end{array}$} & \multicolumn{2}{|c|}{ Lattice parameters $(\AA)$} & \multirow{2}{*}{$\begin{array}{l}\text { Structure } \\
\text { type }\end{array}$} \\
\hline & & Found & Calcd. & $a$ & $c$ & \\
\hline $\mathrm{Na}_{3} \mathrm{~V}_{2}^{\mathrm{III}}\left(\mathrm{PO}_{4}\right)_{3}$ & Green & 3.99 & $4 \cdot 00$ & $8 \cdot 68(2)$ & $22 \cdot 71(2)$ & NASICON \\
\hline $\mathrm{V}^{\mathrm{IV}} \mathrm{V}^{\mathrm{v}}\left(\mathrm{PO}_{4}\right)_{3}$ & Brown & 0.96 & $1 \cdot 00$ & $8 \cdot 52(3)$ & $22 \cdot 02(4)$ & NASICON \\
\hline $\mathrm{Li}_{3} \mathrm{~V}_{2}^{\mathrm{III}}\left(\mathrm{PO}_{4}\right)_{3}$ & Green & 3.95 & $4 \cdot 00$ & $8 \cdot 31(2)$ & $22 \cdot 50(2)$ & NASICON \\
\hline $\mathrm{H}_{3} \mathrm{~V}_{2}^{\mathrm{III}}\left(\mathrm{PO}_{4}\right)_{3}$ & Greenish-black & 3.96 & $4 \cdot 00$ & $8 \cdot 57(3)$ & $22 \cdot 48(3)$ & NASICON \\
\hline $\mathrm{Na}_{3} \mathrm{Ti}^{\mathrm{III}} \mathrm{V}^{\mathrm{III}}\left(\mathrm{PO}_{4}\right)_{3}$ & Brown & 3.00 & 3.00 & $8 \cdot 759(3)$ & $21 \cdot 699(4)$ & NASICON \\
\hline $\mathrm{NaTi}{ }^{i v} \mathrm{~V}^{\mathrm{IV}}\left(\mathrm{PO}_{4}\right)_{3}$ & Green & 0.96 & $1 \cdot 00$ & $8 \cdot 460(5)$ & $21 \cdot 619(8)$ & NASICON \\
\hline $\mathrm{K}_{2} \mathrm{Ti}^{\mathrm{IV}} \mathrm{V}^{\mathrm{lll}}\left(\mathrm{PO}_{4}\right)_{3}$ & Green & $2 \cdot 10$ & $2 \cdot 00$ & $9 \cdot 855(3)$ & - & Langbeinite \\
\hline $\mathrm{Ba}_{1 \cdot 5} \mathrm{~V}_{2}^{\mathrm{lII}}\left(\mathrm{PO}_{4}\right)_{3}$ & Gray & 3.96 & $4 \cdot 00$ & $9 \cdot 884(3)$ & - & Langbeinite \\
\hline $\mathrm{BaKV}_{2}^{\mathrm{III}}\left(\mathrm{PO}_{4}\right)_{3}$ & Greenish-yellow & 3.94 & $4 \cdot 00$ & $9 \cdot 873(2)$ & - & Langbeinite \\
\hline
\end{tabular}

of a preheated mixture of the constituents containing $\mathrm{TiO}_{2} / \mathrm{V}_{2} \mathrm{O}_{5}$. We list, in table 3 , the composition and lattice parameters and, in figure 4, the powder diffraction patterns of some of the new phosphates synthesized by us. We see that the sodium compounds, $\mathrm{Na}_{3} \mathrm{~V}_{2}^{\mathrm{III}}\left(\mathrm{PO}_{4}\right)_{3}$ and $\mathrm{Na}_{3} \mathrm{Ti}^{\mathrm{III}} \mathrm{V}^{\mathrm{III}}\left(\mathrm{PO}_{4}\right)_{3}$, crystallize with the NASICON structure, while the potassium compound $\mathrm{K}_{2} \mathrm{Ti}^{\mathrm{IV}} \mathrm{V}^{\mathrm{III}}\left(\mathrm{PO}_{4}\right)_{3}$ adopts the langbeinite structure.

We anticipated that it would be possible to deintercalate sodium from the NASICON phosphates for the following reasons: It is known that sodium ions have a high mobility in the NASICON framework giving rise to fast sodium ion conductivity (Goodenough et al 1976). The presence of titanium and vanadium in the III oxidation state in $\mathrm{Na}_{3} \mathrm{~V}_{2}\left(\mathrm{PO}_{4}\right)_{3}$ and $\mathrm{Na}_{3} \mathrm{TiV}\left(\mathrm{PO}_{4}\right)_{3}$ would permit oxidative deintercalation of sodium. Indeed we could deintercalate sodium completely from $\mathrm{Na}_{3} \mathrm{~V}_{2}\left(\mathrm{PO}_{4}\right)_{3}$ using $\mathrm{Cl}_{2}$ in $\mathrm{CHCl}_{3}$. The product of deintercalation is the new phosphate $\mathrm{V}_{2}\left(\mathrm{PO}_{4}\right)_{3}$, the reaction being

$$
\mathrm{Na}_{3} \mathrm{~V}_{2}\left(\mathrm{PO}_{4}\right)_{3}+\frac{3}{2} \mathrm{Cl}_{2} \rightarrow \mathrm{V}^{\mathrm{v}} \mathrm{V}^{\mathrm{lv}}\left(\mathrm{PO}_{4}\right)_{3}+3 \mathrm{NaCl}
$$




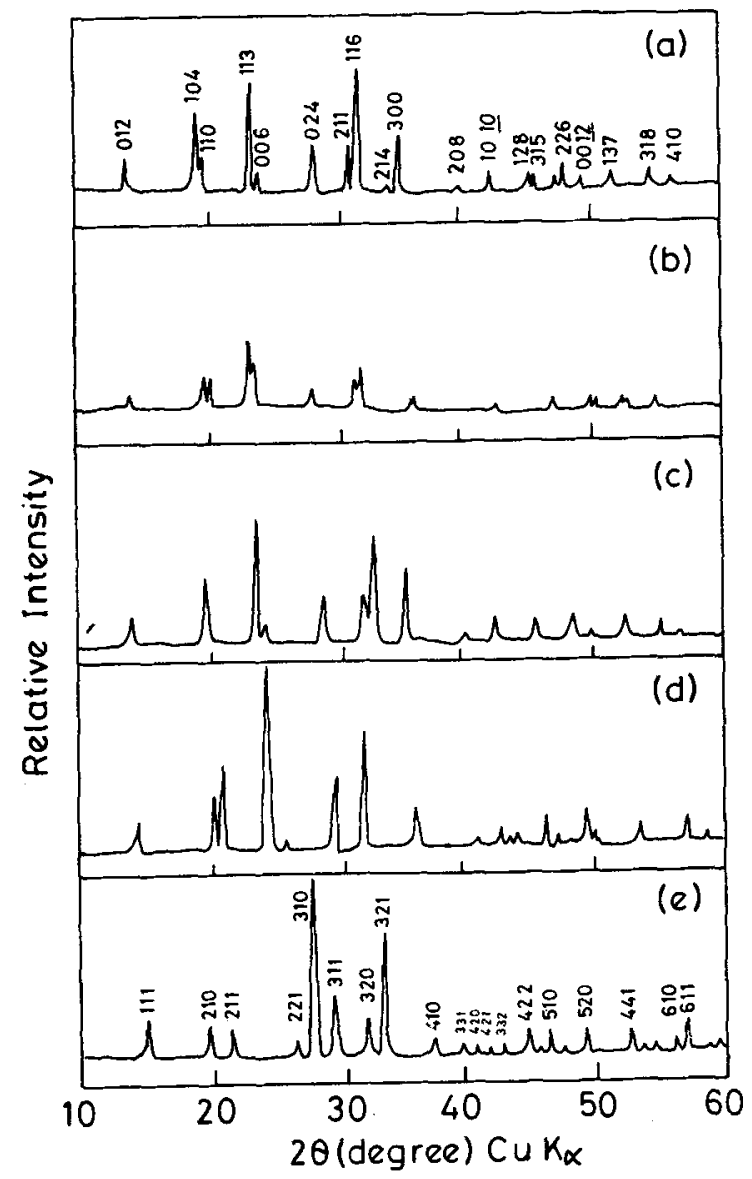

Figure 4. X-ray powder diffraction patterns of (a) $\mathrm{Na}_{3} \mathrm{~V}_{2}\left(\mathrm{PO}_{4}\right)_{3}$, (b) $\mathrm{V}_{2}\left(\mathrm{PO}_{4}\right)_{3}$, (c) $\mathrm{Na}_{3} \mathrm{TiV}$ $\left(\mathrm{PO}_{4}\right)_{3}$, (d) $\mathrm{NaTiV}\left(\mathrm{PO}_{4}\right)_{3}$ and (e) $\mathrm{K}_{2} \mathrm{TiV}\left(\mathrm{PO}_{4}\right)_{3}$.

$\mathrm{V}_{2}\left(\mathrm{PO}_{4}\right)_{3}$ retains the NASICON framework of the parent $\mathrm{Na}_{3} \mathrm{~V}_{2}\left(\mathrm{PO}_{4}\right)_{3}$, showing that the deintercalation is a topochemical reaction. It should be mentioned that, unlike $\mathrm{Nb}_{2}\left(\mathrm{PO}_{4}\right)_{3}$ which could be prepared by a direct solid state reaction (Leclaire et al 1989), $\mathrm{V}_{2}\left(\mathrm{PO}_{4}\right)_{3}$ could not be prepared by a direct method. $\mathrm{V}_{2}\left(\mathrm{PO}_{4}\right)_{3}$, a mixed-valent phosphate having vanadium in the $\mathrm{V}$ and IV states in an 'empty' NASICON framework, is an excellent host material for reductive insertion of electropositive species such as hydrogen and lithium. In table 3 , we list the characteristics of $\mathrm{Li}_{3} \mathrm{~V}_{2}\left(\mathrm{PO}_{4}\right)_{3}$ and $\mathrm{H}_{3} \mathrm{~V}_{2}\left(\mathrm{PO}_{4}\right)_{3}$ prepared by soft-chemical means starting from $\mathrm{V}_{2}\left(\mathrm{PO}_{4}\right)_{3}$ (Gopalakrishnan and Rangan 1992).

Interestingly, a similar deintercalation of sodium from $\mathrm{Na}_{3} \mathrm{TiV}\left(\mathrm{PO}_{4}\right)_{3}$ by chlorine in $\mathrm{CHCl}_{3}$ proceeds to the extent of removal of two-thirds of the sodium atoms giving $\mathrm{NaTiV}\left(\mathrm{PO}_{4}\right)_{3}$. Chemical analysis and magnetic susceptibility establish the formula of the deintercalation product to be $\mathrm{NaTi}^{\mathrm{IV}} \mathrm{V}^{\mathrm{IV}}\left(\mathrm{PO}_{4}\right)_{3}$.

Most importantly, we could not deintercalate potassium from the langbeinite $\mathrm{K}_{2} \mathrm{TiV}\left(\mathrm{PO}_{4}\right)_{3}$ under similar conditions. Even prolonged reaction with chlorine did not result in a significant deintercalation. The lack of deintercalation reactivity of 
this phase in contrast to the facile deintercalation of sodium from $\mathrm{Na}_{3} \mathrm{~V}_{2}\left(\mathrm{PO}_{4}\right)_{3}$ and $\mathrm{Na}_{3} \mathrm{TiV}\left(\mathrm{PO}_{4}\right)_{3}$ is presumably related to the structure. Langbeinite being a true cage structure with small windows connecting the cages does not permit mobility of potassium ions through the $\mathrm{K}_{2} \mathrm{TiV}\left(\mathrm{PO}_{4}\right)_{3}$ framework, while NASICON being a skeletal structure with an interconnected interstitial space permits facile mobility of sodium ions through the framework resulting in deintercalation, provided appropriate transition metal atoms such as Ti(III) and V(III), which can undergo oxidation, is incorporated in the framework.

$\mathrm{KTiOPO}_{4}(\mathrm{KTP})$ is another framework phosphate containing one-dimensional channels parallel to [0 011$]$ where the potassium atoms reside (figure 3) (Tordjman et al 1974). Since it is known that this structure also allows mobility of potassium ions through the channels resulting in ion-exchange and ionic conductivity (Jarman 1989), we expected that it would be possible to oxidatively deintercalate potassium from this structure by incorporating appropriate transition metal atom in the framework. More importantly, since KTP is an unique nonlinear optical (NLO)

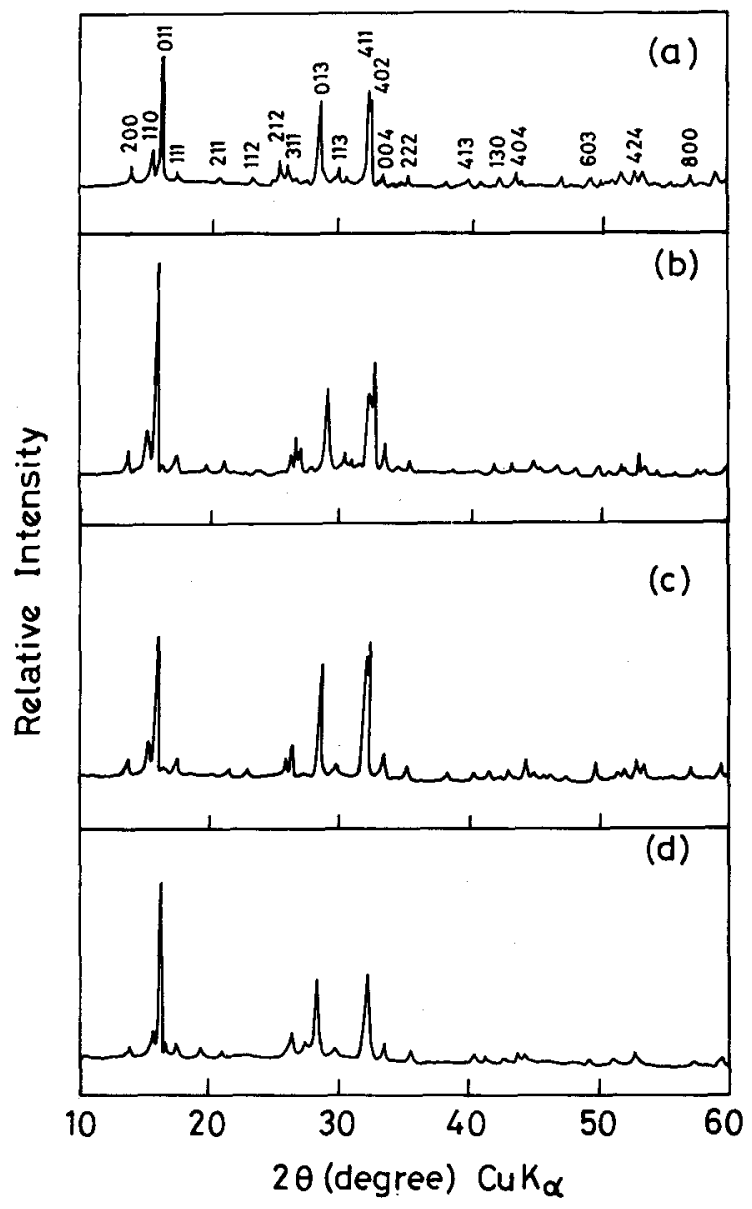

Figure 5. X-ray powder diffraction patterns of (a) $\mathrm{KNb}_{0.5} \mathrm{Ti}_{0.5} O P \mathrm{O}_{4}$, (b) $\mathrm{K}_{0.5} \mathrm{Nb}_{0.5} \mathrm{Ti}_{0.5}$ $\mathrm{OPO}_{4}$, (c) $\mathrm{KNb}_{0.5} \mathrm{~V}_{0.5} \mathrm{OPO}_{4}$ and (d) $\mathrm{K}_{0.5} \mathrm{Nb}_{0.5} \mathrm{~V}_{0.5} \mathrm{OPO}_{4}$. 
Table 4. Composition, colour, lattice parameters and SHG intensity of KTP-like phosphates.

\begin{tabular}{|c|c|c|c|c|c|c|c|}
\hline \multirow[b]{2}{*}{ Composition } & \multirow[b]{2}{*}{ Colour } & \multicolumn{2}{|c|}{$\begin{array}{l}\text { Reducing power } \\
\text { of the sample }\end{array}$} & \multicolumn{3}{|c|}{ Lattice parameters $(\AA)$} & \multirow{2}{*}{$\begin{array}{c}\text { SHG } \\
\text { intensity }\end{array}$} \\
\hline & & Found & Calcd. & $a$ & $b$ & $c$ & \\
\hline $\mathrm{KNb}_{0.5} \mathrm{Ti}_{0.5} \mathrm{OPO}_{4}$ & Dark blue & 0.45 & 0.50 & $12 \cdot 976(5)$ & $6 \cdot 488(4)$ & $10 \cdot 773(6)$ & - \\
\hline $\mathrm{K}_{0.5} \mathrm{Nb}_{0.5} \mathrm{Ti}_{0.5} \mathrm{OPO}_{4}$ & Light blue & - & - & $12 \cdot 879(9)$ & $6 \cdot 402(7)$ & $10 \cdot 659(4)$ & 0.9 \\
\hline $\mathrm{KNb}_{0.5} \mathrm{~V}_{0.5} \mathrm{OPO}_{4}$ & Brown & 0.98 & 1.00 & $12 \cdot 949(6)$ & $6.431(8)$ & $10 \cdot 686(4)$ & - \\
\hline $\mathrm{K}_{0.5} \mathrm{Nb}_{0.5} \mathrm{~V}_{0.5} \mathrm{CPO}_{4}$ & Green & 0.52 & 0.50 & $12 \cdot 801(6)$ & $6.357(4)$ & $10 \cdot 569(5)$ & 0.5 \\
\hline $\mathrm{KTa}_{0.5} \mathrm{~V}_{0.5} \mathrm{OPO}_{4}$ & Grey & 0.98 & $1 \cdot 00$ & $12.985(4)$ & $6.442(3)$ & $10 \cdot 696(4)$ & 一 \\
\hline $\mathrm{K}_{0.5} \mathrm{Ta}_{0.5} \mathrm{~V}_{0.5} \mathrm{OPO}_{4}$ & Yellow & 0.53 & 0.50 & $12 \cdot 819(5)$ & $6 \cdot 367(4)$ & $10 \cdot 615(5)$ & 0.4 \\
\hline
\end{tabular}

*Normalized with respect to that of $\mathrm{KTiOPO}_{4}$ which is taken as unity

material showing second harmonic generation (SHG) of the $1064 \mathrm{~nm}$ radiation, we envisaged that it would be possible to synthesize new NLO materials by deintercalation. To realize this possibility, we prepared new KTP-analogues, $\mathrm{KM}_{0.5} \mathbf{M}_{0.5}^{\prime} \mathrm{OPO}_{4}$ $\left(\mathrm{M}=\mathrm{Nb}^{\mathrm{v}}, \mathrm{Ta}^{\mathrm{v}} ; \mathrm{M}^{\prime}=\mathrm{Ti}^{\mathrm{III}}, \mathrm{V}^{\mathrm{III}}\right)$ and investigated oxidative deintercalation of potassium using $\mathrm{Cl}_{2}$ (figure 5). Deintercalation proceeds according to the following typical example

$$
\mathrm{KNb}_{0.5}^{\mathrm{V}} \mathrm{Ti}_{0.5}^{\mathrm{III}} \mathrm{OPO}_{4}+(1 / 4) \mathrm{Cl}_{2} \rightarrow \mathrm{K}_{0.5} \mathrm{Nb}_{0.5}^{\mathrm{V}} \mathrm{Ti}_{0.5}^{\mathrm{IV}} \mathrm{OPO}_{4}+(1 / 2) \mathrm{KCl},
$$

giving new KTP-analogues, $\mathrm{K}_{0.5} \mathrm{M}_{0.5} \mathrm{M}_{0.5}^{\prime} \mathrm{OPO}_{4}$ (table 4). While the parent materials do not show an SHG response to $1064 \mathrm{~nm}$ radiation, the deintercalated materials, $\mathrm{K}_{0.5} \mathrm{M}_{0.5} \mathrm{M}_{0.5}^{\prime} \mathrm{OPO}_{4}$, do show an SHG response. Both $\mathrm{K}_{0.5} \mathrm{Nb}_{0.5}^{\mathrm{V}} \mathrm{Ti}_{0.5}^{\mathrm{IV}} \mathrm{OPO}_{4}$ and $\mathrm{K}_{0.5} \mathrm{Ta}_{0.5}^{\mathrm{V}} \mathrm{Ti}_{0.5}^{\mathrm{iV}} \mathrm{OPO}_{4}$ prepared by this route show a powder $\mathrm{SHG}$ intensity comparable to that of KTP. The synthesis of these new KTP analogues reveals the importance of $d^{0}$ and $d^{1}$ cations in determining the NLO property of KTP and related materials.

3.3 Layered and three-dimensional vanadium-tungsten oxide hydrates related to $\alpha-\mathrm{MoO}_{3}$ and $\mathrm{WO}_{3} \cdot 1 / 3 \mathrm{H}_{2} \mathrm{O}$

We prepared two new vanadium-tungsten oxide hydrates of the general formula, $\mathrm{H}_{x} \mathrm{~V}_{x} \mathrm{~W}_{1-x} \mathrm{O}_{3} \cdot y \mathrm{H}_{2} \mathrm{O}$ for $x=0.125 ; y=1.5$ and $x=0.33 ; y=0.33$ by acid-leaching of $\mathrm{LiVWO}_{6}$ in aqueous $\mathrm{HNO}_{3} / \mathrm{HCl}$ (table 5). $\mathrm{H}_{0.125} \mathrm{~V}_{0.125} \mathrm{~W}_{0.875} \mathrm{O}_{3} .1 .5 \mathrm{H}_{2} \mathrm{O}(\mathrm{I})$, obtained by leaching $\mathrm{LiVWO}_{6}$ in dilute $\mathrm{HNO}_{3} / \mathrm{HCl}$, crystallizes in a layered, $\alpha-\mathrm{MoO}_{3}$ like structure. I dehydrates around $130^{\circ} \mathrm{C}$ to give a hexagonal phase similar to the one reported by Feist and Davies (1991), $\mathrm{H}_{0.33} \mathrm{~V}_{0.33} \mathrm{~W}_{0.67} \mathrm{O}_{3} .1 / 3 \mathrm{H}_{2} \mathrm{O}$ (II) is another new hydrate obtained by refluxing $\mathrm{LiVWO}_{6}$ with concentrated $\mathrm{HNO}_{3}$. II is isostructural with $\mathrm{WO}_{3} \cdot 1 / 3 \mathrm{H}_{2} \mathrm{O}$ (Gerand et al 1981). II dehydrates topochemically around $330^{\circ} \mathrm{C}$ to give hexagonal- $\mathrm{WO}_{3}$-like (Gerand et al 1979) $\mathrm{H}_{0.33} \mathrm{~V}_{0.33} \mathrm{~W}_{0.67} \mathrm{O}_{3}$ (III). A schematic representation of the structures of the hydrates and their dehydration products is given in figure 6 .

Both I and III, which could be regarded as functionalized derivatives of $\alpha-\mathrm{MoO}_{3}$ and hexagonal $\mathrm{WO}_{3}$ structures, exhibit redox and acid-base intercalation/insertion reactivity characteristic of layered and tunnel structures. Thus, I readily intercalates 
Table 5. Composition and lattice parameters of vanadium-tungsten oxide hydrates and their derivatives.

\begin{tabular}{|c|c|c|c|}
\hline \multirow[b]{2}{*}{ Composition } & \multicolumn{3}{|c|}{ Lattice parameters $(\AA)$} \\
\hline & $a$ & $b$ & $c$ \\
\hline $\mathrm{H}_{0.125} \mathrm{~V}_{0.125} \mathrm{~W}_{0.875} \mathrm{O}_{3} \cdot 1 \cdot 5 \mathrm{H}_{2} \mathrm{O}(\mathrm{I})$ & $7 \cdot 77(3)$ & $13 \cdot 87(6)$ & $7 \cdot 44(3)$ \\
\hline $\mathrm{H}_{0.33} \mathrm{~V}_{0.33} \mathrm{~W}_{0.6} \mathrm{O}_{3} \cdot 1 / 3 \mathrm{H}_{2} \mathrm{O}(\mathrm{II})$ & $7 \cdot 22(3)$ & $12 \cdot 54(7)$ & $7 \cdot 66(4)$ \\
\hline $\mathrm{H}_{0.33} \mathrm{~V}_{0.33} \mathrm{~W}_{0.6} \mathrm{O}_{3}(\mathrm{III})$ & $7 \cdot 25(4)$ & - & $3 \cdot 87(2)$ \\
\hline $\mathrm{K}_{0.18}\left[\mathrm{H}_{0.125} \mathrm{~V}_{0.125} \mathrm{~W}_{0.875} \mathrm{O}_{3} \cdot 1 \cdot 5 \mathrm{H}_{2} \mathrm{O}\right]$ & $7 \cdot 63(3)$ & 13.74(7) & $7 \cdot 41(3)$ \\
\hline$\left(\mathrm{NH}_{4}\right)_{0.125} \mathrm{~V}_{0.125} \mathrm{~W}_{0.875} \mathrm{O}_{3} \cdot 1.5 \mathrm{H}_{2} \mathrm{O}$ & $7 \cdot 88(3)$ & $24 \cdot 70(9)$ & $7 \cdot 17(2)$ \\
\hline$\left(n-\mathrm{C}_{6} \mathrm{H}_{13} \mathrm{NH}_{2}\right)_{0.58} \mathrm{H}_{0.125} \mathrm{~V}_{0.125} \mathrm{~W}_{0.875} \mathrm{O}_{3} \cdot 1 \cdot 5 \mathrm{H}_{2} \mathrm{O}$ & $7 \cdot 73(4)$ & $38 \cdot 4(2)$ & $7 \cdot 43(4)$ \\
\hline$\left(n-\mathrm{C}_{10} \mathrm{H}_{21} \mathrm{NH}_{2}\right)_{0.61} \mathrm{H}_{0.125} \mathrm{~V}_{0.125} \mathrm{~W}_{0.875} \mathrm{O}_{3} \cdot 1 \cdot 5 \mathrm{H}_{2} \mathrm{O}$ & $7 \cdot 78(9)$ & $58 \cdot 0(6)$ & $7 \cdot 55(9)$ \\
\hline $\mathrm{H}_{0.90}\left[\mathrm{H}_{0.33} \mathrm{~V}_{0.33}^{2.61} \mathrm{~W}_{0.67} \mathrm{O}_{3}\right]$ & $7 \cdot 26(2)$ & - & $3 \cdot 87(2)$ \\
\hline $\mathrm{K}_{0.33}\left[\mathrm{H}_{0.33} \mathrm{~V}_{0.33} \mathrm{~W}_{0.67} \mathrm{O}_{3}\right]$ & $7 \cdot 25(4)$ & - & $3 \cdot 87(3)$ \\
\hline$\left(\mathrm{NH}_{4}\right)_{0.30} \mathrm{H}_{0.03} \mathrm{~V}_{0.33} \mathrm{~W}_{0.67} \mathrm{O}_{3}$ & $7 \cdot 24(2)$ & - & $3 \cdot 86(1)$ \\
\hline
\end{tabular}
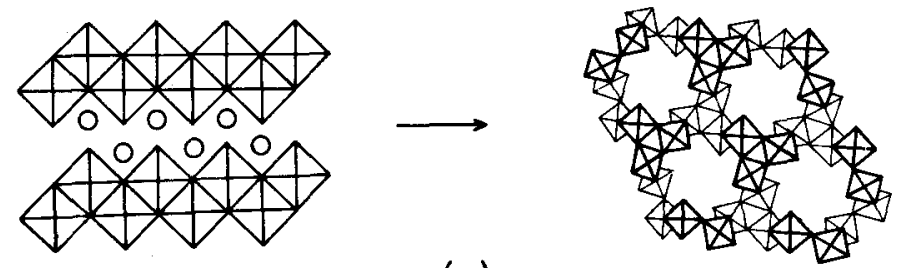

(a)

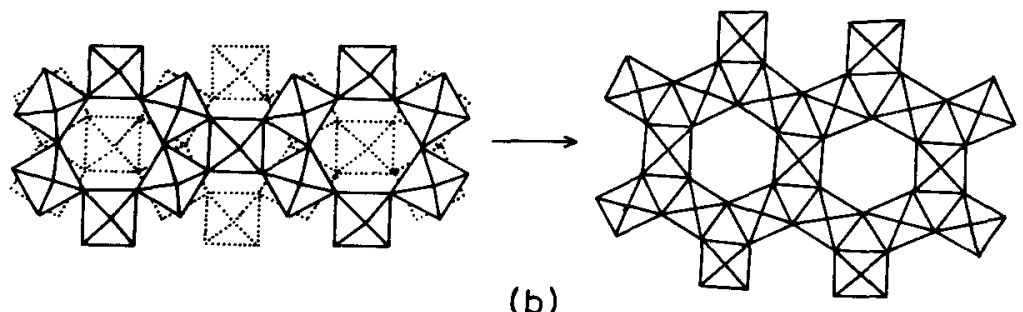

Figure 6. Schematic representation of the structural changes accompanying dehydration of (a) $\mathrm{H}_{0.125} \mathrm{~V}_{0.125} \mathrm{~W}_{0.875} \mathrm{O}_{3} \cdot 1 \cdot 5 \mathrm{H}_{2} \mathrm{O}$ and (b) $\mathrm{H}_{0.33} \mathrm{~V}_{0.33} \mathrm{~W}_{0.67} \mathrm{O}_{3} \cdot 1 / 3 \mathrm{H}_{2} \mathrm{O}$.

$n$-alkylamines resulting in large layer expansions characteristic of layered structures (table 5). Especially significant is the insertion of ammonia molecules into the hexagonal tunnels of III through an acid-base reaction involving the acidic protons.

In summary, the foregoing examples of synthesis of oxide materials show that imaginative routes to synthesis of solids can be developed based on a knowledge of crystal chemistry and chemical reactivity combined with painstaking efforts at the laboratory bench. 


\section{Acknowledgements}

We thank Professor C N R Rao for valuable encouragement and support and the Department of Science and Technology, Government of India, for financial support. Thanks are also due to Dr C.K Subramanian and Mr B R Prasad of the Department of Physics, Indian Institute of Science, Bangalore, for testing the SHG response of the phosphates.

\section{References}

Colville A A and Geller S 1971 Acta Crystallogr. B27 2311

Dion M, Ganne M and Tournoux M 1981 Mater. Res. Bull. 161429

Dion M, Ganne M, Tournoux M and Ravez J 1984 Rev. Chim. Miner. 2192

Disalvo F J 1990 Science 247649

Feist T P and Davies P K 1991 Chem. Mater. 31011

Gerand B, Nowogrocki G and Figlarz M 1981 J. Solid State Chem. 38312

Gerand B, Nowogrocki G, Guenot J and Figlarz M 1979 J. Solid State Chem. 29429

Goodenough J B, Hong H Y-P and Kafalas J A 1976 Mater. Res. Bull. 11203

Gopalakrishnan J 1984 Proc. Indian Acad. Sci. (Chem. Sci.) 93421

Gopalakrishnan J 1993 In Chemistry of advanced materials (ed.) C N R Rao (Oxford: Blackwell) p. 41 Gopalakrishnan J and Bhat V 1987 Inorg. Chem. 264299

Gopalakrishnan J, Bhat V and Raveau B 1987 Mater. Res. Bull. 22413

Gopalakrishnan J and Rangan K K 1992 Chem. Mater. 4745

Hong H Y-P 1976 Mater. Res. Bull. 11173

Jacobson A J, Johnson J W and Lewandowski J T 1985 Inorg. Chem. 243727

Jacobson A J, Johnson J W and Lewandowski J T 1987 Mater. Res. Bull. 2245

Jacobson A J, Lewandowski J T and Johnson J W 1986 J. Less-Common Met. 116137

Jarman R H 1989 Solid State Ionics 32/33 45

Leclaire A, Borel M M, Grandin A and Raveau B 1989 Acta Crystallogr. Sect. C 45699

Rao C N R 1993 Mater. Sci. Eng. B 181

Rao C N R and Gopalakrishnan J 1987 Acc. Chem. Res. 20228

Ruddlesden S N and Popper P 1957 Acta Crystallogr. 10538

Ruddlesden S N and Popper P 1958 Acta Crystallogr. 1154

Stein A, Keller S W and Mallouk T E 1993 Science 2591558

Tordjman I, Masse R and Guitel J C 1974 Z. Kristallogr. 139103

Uma S, Raju A R and Gopalakrishnan J 1993 J. Mater. Chem. 3709

Zemann A and Zemann J 1957 Acta Crystallogr. 10409 